\title{
SLANG WORDS USED BY MILLENNIAL GENERATION IN INSTAGRAM
}

\author{
${ }^{I}$ STKIP Budidaya Binjai \\ trindah.rizky@gmail.com \\ ${ }^{2}$ Universitas Muhammadiyah Sumatera Utara \\ rakhmatwahyudin@umsu.ac.id \\ ${ }^{3}$ STKIP Budidaya Binjai \\ efrinipanjaitan@gmail.com \\ ${ }^{4}$ STKIP Budidaya Binjai \\ juliantinasebayang@gmail.com
}

${ }^{1}$ Tri Indah Rezeki, ${ }^{2}$ Rakhmat Wahyudin Sagala, ${ }^{3}$ Efrini Panjaitan, ${ }^{4}$ Juliantina

\begin{abstract}
ABSTRAK
Indonesia recognizes that Bahasa as a national language which has function as unity language for its society. In fact, the tendency of society especially millennial generation used slang in daily conversation is higher than used Bahasa itself. This study aims to analyse the phenomenon of slang words used by millennial generation in Instagram. The scope of this study is to investigate types of slang used by millennial generation in Instagram, how model of slang used by millennial generation and why millennial generation used slang words in Instagram. Descriptive qualitative research was applied in this study and obtained the data from the discourse of 30 millennial generations in Instagram. The data was obtained from observation, interview and documentation. The result of the data showed that millennial generation used slang words in their communication in Instagram namely there were 31 slang words found in their caption in Instagram. These words contained five types of slang; fresh and creative; flippant; imitative; acronym; and clipping. The millennial generation used slang in Instagram because some reasons such as to address, to initiate relax conversation, to humiliate, to express impression and to show intimacy.
\end{abstract}

Keywords: Slang, Types of slang, Reasons of slang, millennial generation

\section{INTRODUCTION}

In communication, the role of language is very important because the information which is conveyed need language. Language is one of important thing in human society's life to communicate each other (Rezeki, 2018).

The meaning of language is not only related to the choice of words but also how the way to convey it. When the speaker cannot convey his/her message by using one language, the speaker needs to change the language to be more understood (Sagala, Rakhmat \& Rezeki, 2018). Nowadays, slang has been a phenomenon in millennial generation era, not only for them who live in city but also for them who live in villages have known slang language as if it has been a trend in millennial era. While on the other hand, parents and adults complained about the grammar and speech of

their children's language which was difficult to be understood. Moreover, social media is growing at this time, which starts from Send Message Short (SMS) to Instagram, Facebook, WhatsApp, Twitter, etc. The social media has accompanied the spread and the development of slang in millennial generation era, not only its pronunciation but also its writing. Whereas, educational environment certainly teaches students how to use good grammar in Bahasa but in reality, these students still come out from the use of correct language and prefer to use slang in their communication. Hornby (1974) states that slang is words, phrases, meanings of 
words, commonly used in talk among friends or colleagues, but not suitable for good writing or formal occasions. Slang is language (words, phrases, and usages) of an informal register that members of special groups like teenagers, musicians, or criminals favour in order to establish group identity. Slang is usually popular among millennial generation.

Allan and Burridge (2006) divided the types of slang into five such as fresh and creative means the slang word has new vocabularies in order to describe something in informal situation; flippant means slang is made by two words or more in which the word composed not correlated with the denotative meaning; imitative means the slang word imitating or derived from the Standard English word; acronym means it is constructed by the result of the word formed by the first letter of each word in a phrase or made by initials from a group of words or syllables and pronounced them as a new word; and clipping means slang word is made by deleting some part of longer word becomes a shorter form in the same meaning. Allan and Burridge (2006) also explain that there are seven different reasons of slang; to address, to initiate relax conversation, to humiliate, to form intimate atmosphere, to express impression, to reveal anger, and to show intimacy.

Slang is often used by millennial generation in daily life conversation. According to Strauss (2000), millennial generation refers to the generation of people born early 1980s as starting birth year and the mid 1990s to early 2000s as ending birth years. Slang words used by millennial generation can be found in their social media such as Instagram, Facebook, WhatsApp, Twitter, etc.

By using slang words, Indonesia society especially millennial generation have difficulties to communicate by using Bahasa properly. This phenomenon happened because of applying new language which are considered as creativity for them. It makes possibly the next generation are not able to know and to use Bahasa as a standard and national language. Today, millennial generation especially teenagers prefer to use slang language than formal language. Based on observation, the slang language is more comfortable to be used in daily conversation such as in chatting, direct, conversation or in other social network media. From the reality, this study was done to identify the phenomenon of slang words used by millennial generation which focused on analyse the types of slang used by millennial generation in social media; the meaning of slang used by millennial generation in Instagram and reasons why millennial generation used slang in Instagram.

\section{METHOD}

Descriptive qualitative research was applied in this study. The qualitative research is used to investigate the social phenomenon (Trochim and William, 2006). Descriptive qualitative is one of the research procedures which produce descriptive data in form of speech and the behaviour of those being observed (Bogdan and Taylor, 1992). For this case, Bogdan and Biklen (1982) recommended the characteristic of qualitative research has the natural setting and the researcher as a key instrument. It means that the researcher is an actor to collect the data (Moleong, 2005).

The data was obtained from the discourse of 30 millennial generations in Instagram which contain slang in their caption or their stories. Then, the data was analysed based on type and meaning of slang. Researchers also used instruments in this study such as observation, interview, and documentation. To check the data validation, the triangulation was used in this research by combining the information from both the discourse of millennial generation in Instagram and the techniques of data collection, i.e. documentation and interview.

\section{RESULT AND DISCUSSION}

\section{A. Types and Meaning of slang words used by Millennial Generation in Instagram}

From the data, the millennial generation used these types in their Instagram. The data was shown in table 1.1. 


\begin{tabular}{|c|c|c|c|c|c|c|c|}
\hline \multirow[b]{2}{*}{ No. } & \multirow[b]{2}{*}{ Discourse } & \multicolumn{5}{|c|}{ Types of SAOS } & \multirow[b]{2}{*}{ Meaning } \\
\hline & & $\begin{array}{l}\text { Fresh and } \\
\text { creative }\end{array}$ & Flippant & Imitative & Acronym & Clipping & \\
\hline 1. & $\begin{array}{l}\text { Sерири } \\
\text { gaess }\end{array}$ & & & $\sqrt{1}$ & & & $\begin{array}{l}\text { Guy or } \\
\text { guys } \\
\text { means } \\
\text { teman, } \\
\text { kawan }\end{array}$ \\
\hline 2. & $\begin{array}{l}\text { Diam bukan } \\
\text { berarti } \\
\text { baper }\end{array}$ & & & & $\sqrt{ }$ & & $\begin{array}{l}\text { Bawa } \\
\text { Perasaa } \\
n\end{array}$ \\
\hline 3. & $\begin{array}{l}\text { Hayuk } \\
\text { segera ke } \\
\text { PRSU. }\end{array}$ & $\sqrt{ }$ & & & & & Ayo \\
\hline 4. & $\begin{array}{l}\text { Jangan } \\
\text { suka } \\
\text { nyinyir }\end{array}$ & $\sqrt{ }$ & & & & & $\begin{array}{l}\text { Cerewet, } \\
\text { membica } \\
\text { rakan } \\
\text { orang } \\
\text { lain } \\
\text { dengan } \\
\text { kata- } \\
\text { kata } \\
\text { pedas }\end{array}$ \\
\hline 5. & $\begin{array}{l}\text { This is my } \\
\text { first } \\
\text { experience } \\
\text { loh. LOL }\end{array}$ & & & & $\sqrt{ }$ & & $\begin{array}{l}\text { Laugh } \\
\text { Out } \\
\text { Loud, } \\
\text { Lots of } \\
\text { Luck, } \\
\text { Lots of } \\
\text { Love }\end{array}$ \\
\hline 6. & $\begin{array}{l}\text { Manfaatkan } \\
\text { waktu } \\
\text { sebaik } \\
\text { mungkin } \\
\text { untuk } \\
\text { jenjalan }\end{array}$ & $\sqrt{ }$ & & & & & $\begin{array}{l}\text { Jalan- } \\
\text { Jalan }\end{array}$ \\
\hline 7. & $\begin{array}{l}\text { Gak perlu } \\
\text { digubris }\end{array}$ & $\sqrt{ }$ & & & & & $\begin{array}{l}\text { Memper } \\
\text { dulikan }\end{array}$ \\
\hline
\end{tabular}


Jurnal Serunai Bahasa Inggris

Vol 11, No. 2, Oktober 2019

e-ISSN 2621-010X

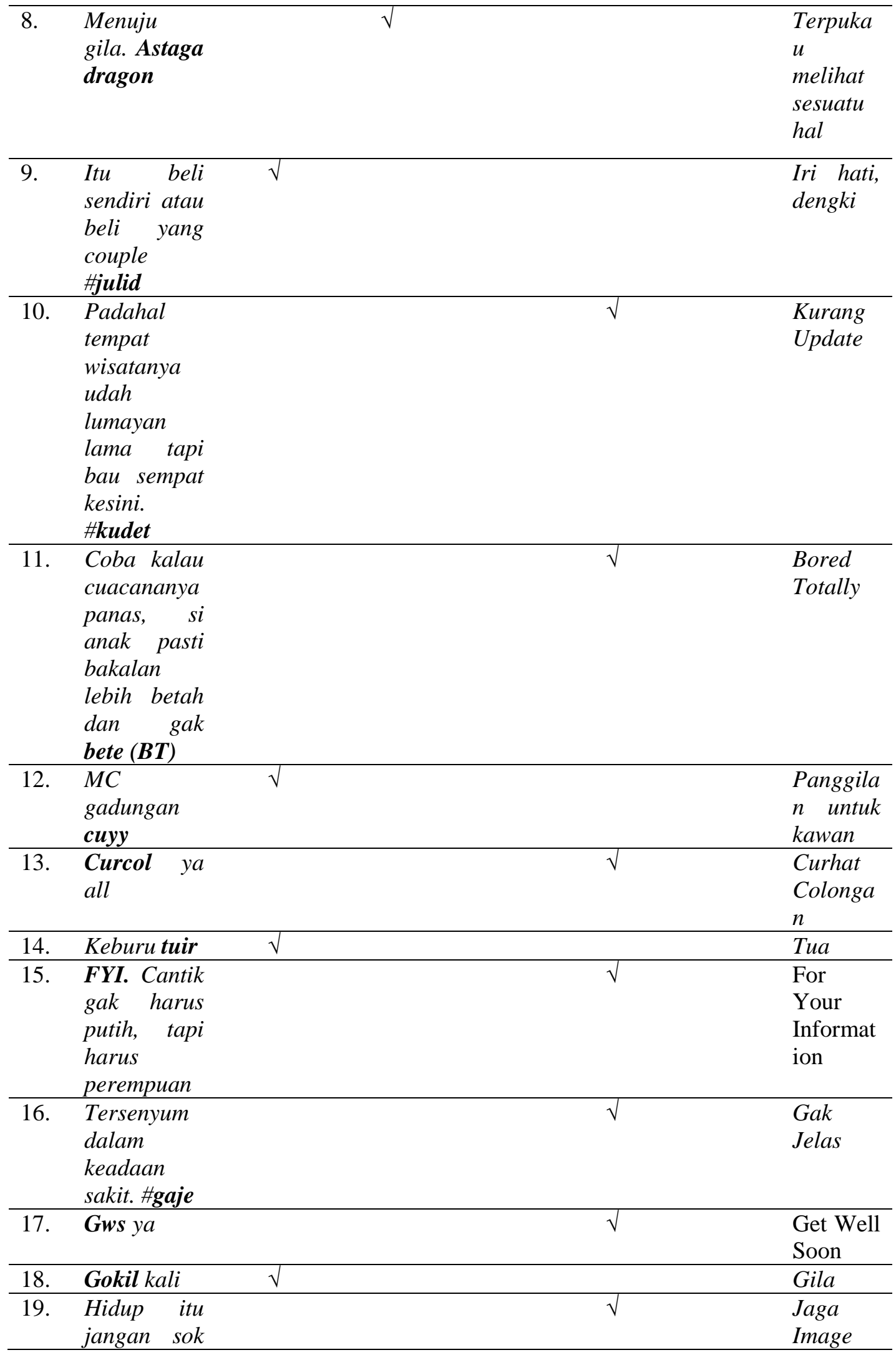


Jurnal Serunai Bahasa Inggris

Vol 11, No. 2, Oktober 2019

e-ISSN 2621-010X

\begin{tabular}{|c|c|c|c|c|}
\hline & jaim & & & \\
\hline 20. & $\begin{array}{l}\text { Jika Tuhan } \\
\text { menjodohka } \\
\text { nmu } \\
\text { denganku, } \\
\text { pacarmu } \\
\text { bisa apa? } \\
\text { \#jojoba }\end{array}$ & & $\sqrt{ }$ & $\begin{array}{l}\text { Jomblo- } \\
\text { Jomblo } \\
\text { Bahagai } \\
\text { a }\end{array}$ \\
\hline 21. & $\begin{array}{l}\text { Salfok ama } \\
\text { mobil }\end{array}$ & & $\sqrt{ }$ & $\begin{array}{l}\text { Salah } \\
\text { Fokus } \\
\end{array}$ \\
\hline 22. & $\begin{array}{l}\text { Keistimewa } \\
\text { an dari } \\
\text { hidup } \\
\text { adalah } \\
\text { menjadi diri } \\
\text { sendiri } \\
\text { \#kuper }\end{array}$ & & $\sqrt{ }$ & $\begin{array}{l}\text { Kurang } \\
\text { Pergaula } \\
\mathrm{n}\end{array}$ \\
\hline 23. & $\begin{array}{l}\text { Bikin orang } \\
\text { gak kelar- } \\
\text { kelar } \\
\text { ngejurnal }\end{array}$ & $\sqrt{ }$ & & selesai \\
\hline 24. & Kzl gak sih & $\sqrt{ }$ & & Kesel \\
\hline 25. & $\begin{array}{l}\text { Lucunya } \\
\text { ketika } \\
\text { seseorang } \\
\text { membencim } \\
\text { u karena } \\
\text { merasa } \\
\text { tersaingi. } \\
\text { Leh uga }\end{array}$ & & & $\begin{array}{l}\text { Boleh } \\
\text { Juga }\end{array}$ \\
\hline 26. & $\begin{array}{l}\text { Ngopi } y u . \\
\text { \#mager }\end{array}$ & & $\sqrt{ }$ & $\begin{array}{l}\text { Males } \\
\text { Gerak }\end{array}$ \\
\hline 27. & nongki & $\sqrt{ }$ & & $\begin{array}{l}\text { Nongkro } \\
\text { ng }\end{array}$ \\
\hline 28. & pewe & & $\sqrt{ }$ & $\begin{array}{l}\text { Posisi } \\
\text { Wenak } \\
\text { enak) }\end{array}$ \\
\hline 29. & $\begin{array}{lr}\text { Belum } & \text { nih. } \\
\text { Padahal } & \\
\text { keknya } & \\
\text { rumah } & \text { dia } \\
\text { beda } & 2 \\
\text { station } & \\
\text { sama } & \text { gua } \\
\text { \#sotoy } & \\
\end{array}$ & $\sqrt{ }$ & & Sok tahu \\
\hline 30. & $\begin{array}{l}\text { Rainbow, } \\
\text { unch }\end{array}$ & $\sqrt{ }$ & & $\begin{array}{l}\text { Enak } \\
\text { dong, } \\
\text { asyik } \\
\text { dong }\end{array}$ \\
\hline
\end{tabular}




\begin{tabular}{ll}
\hline $31 \quad$ Cantik \\
belum tentu \\
tembem, \\
tembem \\
udah pasti \\
cantik \\
\#woles \\
\hline
\end{tabular}

\section{B. Model of Slang}

This study was conducted to create a product namely model of slang. This model was created by the authors based on the result of the study. It can be shown in figure 1.1:

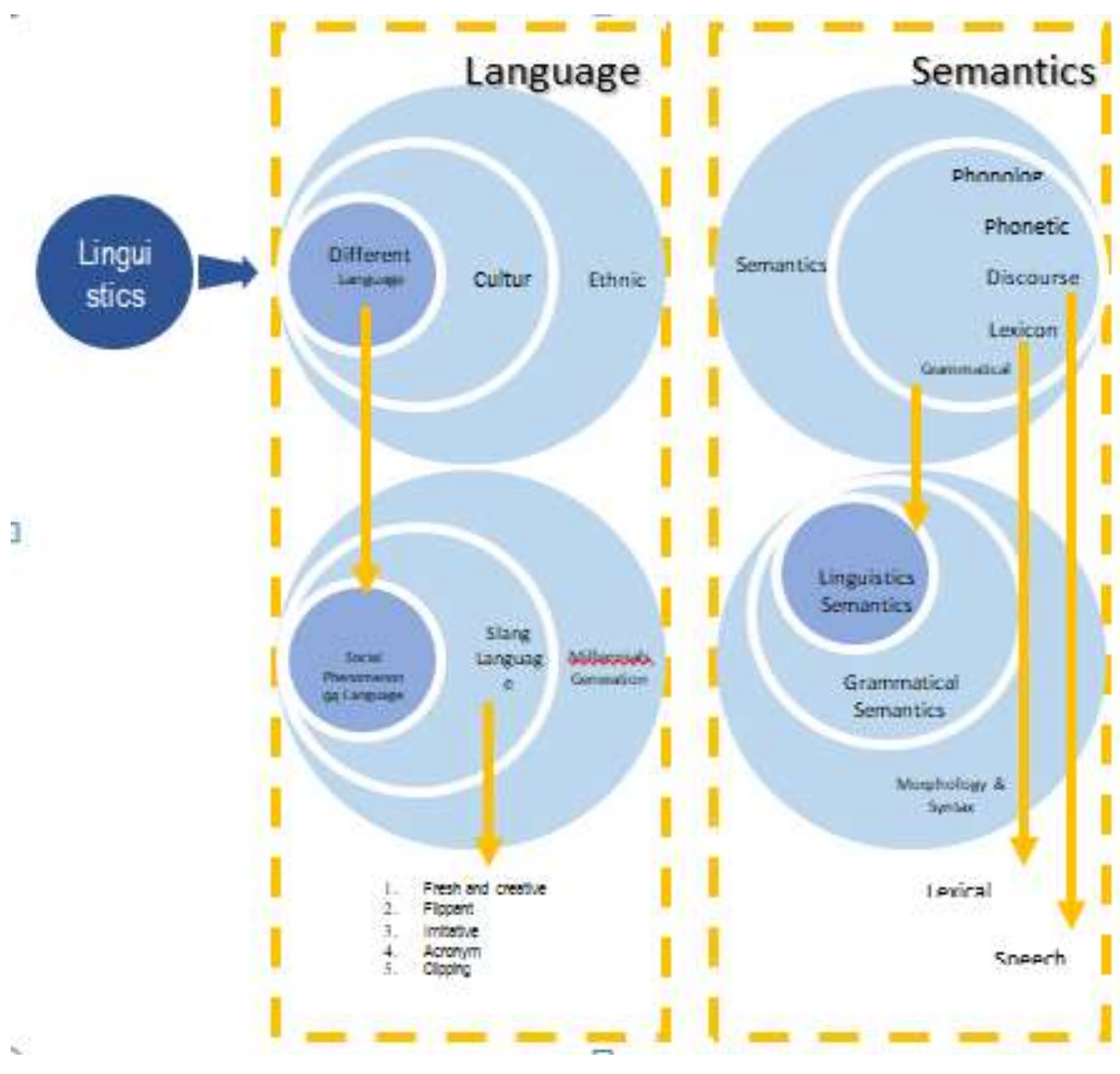


Model of Slang (Tri Indah Rezeki, Rakhmat Wahyudin Sagala, 2019)

\section{Reasons of Slang used by Millennial Generation}

Based on interview to the millennial generation who use slang in their Instagram, most reasons why millennial generation use slang in their social media are to address, to initiate relax conversation, to express impression, to humiliate and to show intimacy. These are the example of the data:

a. To address

Example: Sepupu gaess

The speaker used "gaess" to addresser friends. Gaess means teman, kawan

b. To initiate relax conversation

Example: Ngopi yu. \#mager

The speaker used hastag "mager" to start his conversation to his friend. Mager means males gerak

c. To express impression

Example: Rainbow, unch

the speaker used "unch" to express her impressio of something. Unch means enak dong, asyik dong

d. To show intimacy

Example: Gws ya

The speaker used "Gws" to give a pray to her friend. Gws means get well soon.

e. To humiliate

Example: Itu beli sendiri atau beli yang couple \#julid

The speaker used hastag "julid" to tease another people.

\section{CONCLUSION}

Millennial generation often used slang words in their daily conversation especially in social media such as Instagram. From the data which was obtained from 30 millennial generations, there were 31 slang words used in Instagram. They used slang because some reasons such as to address, to initiate relax conversation, to express impression, to humiliate and to show intimacy.

\section{ACKNOWLEDGEMENT}

This study supported by SIMLIMTABMAS. Department of Research and Community Service (DRPM). Direktorat Jenderal Penguatan Riset dan Pengembangan. The Ministry of Research, Technology and Higher Education (Kemenristekdikti) according to research contract in 2019

\section{REFERENCES}

Allan, K., Burridge, K. 2006. Forbidden Words: Taboo and The Cencoring of Language. Cambridge: CUP

Atlantis Press, 2018.Strauss, W. 2000. Millennials Rising: The Next Great Generation. Cartoons by R.J. Matson. New York: Vintage Original

Bogdan, R.C, and Biklen, S.K. 1982. Qualitative Research for Education: An Introduction to Theory and Methods. Boston: Allyn and Bacon, Inc

Bogdan and Biklen. 1992. Qualitative Research for Education: An Introduction to Theory and Method. Boston: Allyn and Bacon Inc.

Hornby, A.S.1974. Oxford Advanced Learner Dictionary. London Moleong, L.J. 2005. Metodologi Penelitian Kualitatif. Bandung: Remaja Rosdakarya

Rezeki, Tri Indah. "Kontekstual Code Switching Dalam Seminar Proposal Program Studi Pendidikan Bahasa Inggris." Jurnal Serunai Bahasa Inggris 10.2 (2018): 1-7.

Sagala, Rakhmat Wahyudin, Tri Indah Rezeki, and Busmin Gurning. "Grammatical and 
Contextual Code Switching in the English Department Proposal Seminar." $3 r d$ Annual International Seminar on Transformative Education and Educational Leadership (AISTEEL 2018).
Trochim and William M.K. 2006. Descriptive Statistics. Research Methods Knowledge Base. Retrieved March $14^{\text {th }} 2011$ 